\title{
Effect of Integrated Nutrient Management of Oat on Succeeding Maize Crop
}

\author{
Alankar Singh ${ }^{1 *}$, Pallavi $^{2}$ and S.N. Dubey ${ }^{3}$ \\ ${ }^{1}$ K.V.K. Ranichauri, UUHF, Bharsar, India \\ ${ }^{2}$ Department of Agriculture, Dolphin (PG) Institute of Biomedical \& Natural Sciences, \\ Dehradun, India \\ ${ }^{3}$ A.S.College, Lakhaoti, Bulandshahar, U.P., India \\ *Corresponding author
}

\begin{tabular}{|c|c|}
\hline & A B S T R A C T \\
\hline $\begin{array}{l}\text { Maize crop, } \\
\text { Integrated nutrient } \\
\text { management and } \\
\text { Yield }\end{array}$ & \multirow{3}{*}{$\begin{array}{l}\text { The treatments comprised of three varieties of oat }(\text { Kent, JHO 822, JHO 851) as the main } \\
\text { plot treatments and nine integrated nutrient management viz; } 50 \% \text { of Recommended dose } \\
\text { of Fertilizer }(\mathrm{RDF})\left(\mathrm{F}_{1}\right), 75 \% \text { of RDF }\left(\mathrm{F}_{2}\right), 100 \% \text { of RDF }\left(\mathrm{F}_{3}\right), 50 \% \text { of RDF }+ \text { Vermi } \\
\text { Compost }\left(\mathrm{F}_{4}\right), 50 \% \text { of RDF }+ \text { Azotobactor }\left(\mathrm{F}_{5}\right), 50 \% \text { of RDF }+ \text { Vermi Compost }+ \\
\text { Azotobactor }\left(\mathrm{F}_{6}\right), 75 \% \text { of RDF }+ \text { Vermi Compost }\left(\mathrm{F}_{7}\right), 75 \% \text { of RDF }+ \text { Azotobactor }\left(\mathrm{F}_{8}\right) \\
\text { and } 75 \% \text { of RDF }+ \text { Vermicompost }+ \text { Azotobactor }\left(\mathrm{F}_{9}\right) \text { as the sub plot treatments } \\
\text { followed by maize crop. Number of plants } \mathrm{m}^{-2}, \text { plant height, } 1000 \text {-grain weight and grain } \\
\text { yield of maize affected significantly by different nutrient management treatments given to } \\
\text { previous oat crop. More number of maize plants } \mathrm{m}^{-2}, \text { plant height, 1000-grain weight were } \\
\text { noted in plots previously treated with } 75 \% \text { of RDF }+ \text { Vermi Compost }+ \text { Azotobactor } \\
\text { which was statistically equal to that of } 50 \% \text { of RDF }+ \text { Vermi Compost }+ \text { Azotobactor } \\
\text { followed by } 75 \% \text { of RDF }+ \text { Vermi Compost. }\end{array}$} \\
\hline Article Info & \\
\hline $\begin{array}{l}\text { Accepted: } \\
\text { 10 January } 2019 \\
\text { Available Online: } \\
10 \text { February } 2019\end{array}$ & \\
\hline
\end{tabular}

\section{Introduction}

Maize (Zea mays L) is also an important crop as a source of food and maize straw used as livestock feed in India which is grown in kharif season after oat.

The application of organic manure and biofertilizer in oat crop may have the residual effect on maize grain yield during subsequent planting season. Addition of organic manures to cultivated land helps recycle nutrients and reduce fertilizer costs in crop production systems. Moreover, the soil nutrient availability derived from organic manure application is not well known. In addition, application of organic manure or others organic wastes may also generate a positive residual effect that should be taken into account when planning the next crop (Eghball et al., 2014; Hirzel et al., 2007).

Rowell (1994) describes it as reasons to fertilizers after the first season of application. 
Warren (1992) considers the attribute as a rather loose way of indicating benefit from old fertilizer application in subsequent seasons. Assessment of residual effects is of benefit to smallholder farmers as it aims at reducing fertilizer inputs.

The presence of residual effects in nirtogen application therefore has implications on fertilizer management strategies in subsequent planting seasons. Residual effect of fertilizer can greatly affect the yield.

The residual $\mathrm{N}$ effect obtained with organic residues is mainly because some $\mathrm{N}$ is adsorbed or incorporated into the clay and organic soil fraction and is immobilized by soil microbial biomass (Jensen et al., 2015; Sainz et al., 2004). Sorensen and Amato (2002) found that the residual $\mathrm{N}$ effect associated with the application of pig slurry to a barley (Hordeum vulgare L.) and ryegrass (Lolium perenne L.) crop rotation were about 2 to $4 \%$ and 1 to $3 \%$ of the $\mathrm{N}$ applied as manure in the second and third year, respectively.

\section{Materials and Methods}

The experiment was conducted in Agricultural Research Farm of Amar Singh (PG) College, Lakhaoti, Bulandshar (U.P.) during 2009-10 and 2010-11 on a well drained sandy loam soil. The experiment was carried out at the same site and lay out during both the years.

The experimental site is situated at a latitude of $28.4^{\circ}$ North and longitude of $77.1^{\circ}$ East with an altitude of 207.1 metre above the mean sea level. Generally, temperature is maximum during May-June and lowest in December-January. The experiment was laid out in factorial randomized block design with three replications at the same site during both the years.
A. Varieties:

i. $\quad$ Kent $\left(\mathrm{V}_{1}\right)$

ii. $\quad \mathrm{JHO}-822\left(\mathrm{~V}_{2}\right)$

iii. $\mathrm{JHO}-851\left(\mathrm{~V}_{3}\right)$

B. Fertilizer Management:

i. $50 \%$ of Recommended dose of Fertilizer (RDF) $\left(\mathrm{F}_{1}\right)$

ii. $\quad 75 \%$ of $\operatorname{RDF}\left(\mathrm{F}_{2}\right)$

iii. $\quad 100 \%$ of $\mathrm{RDF}\left(\mathrm{F}_{3}\right)$

iv. $\quad 50 \%$ of RDF + Vermi Compost $\left(\mathrm{F}_{4}\right)$

v. $\quad 50 \%$ of RDF + Azotobactor $\left(\mathrm{F}_{5}\right)$

vi. $\quad 50 \%$ of $\mathrm{RDF}+$ Vermi Compost + Azotobactor $\left(\mathrm{F}_{6}\right)$

vii. $\quad 75 \%$ of $\mathrm{RDF}+$ Vermi Compost $\left(\mathrm{F}_{7}\right)$

viii. $\quad 75 \%$ of $\mathrm{RDF}+$ Azotobactor $\left(\mathrm{F}_{8}\right)$

ix. $\quad 75 \%$ of RDF + VermiCompost + Azotobactor $\left(\mathrm{F}_{9}\right)$

Observation taken in maize crop: Number of plants/m² , Plant height, 1000 grain weight (g) and Yield (kg/ha).

\section{Results and Discussion}

Number of plants $\mathrm{m}^{-2}$, plant height, 1000grain weight and grain yield of maize affected significantly by different nutrient management treatments. More number of maize plants $\mathrm{m}^{-2}$, plant height, 1000-grain weight were noted in plots previously treated with $75 \%$ of RDF + Vermi Compost + Azotobactor which was statistically equal to that of $50 \%$ of RDF + Vermi Compost + Azotobactor followed by $75 \%$ of RDF + Vermi Compost.

This may be due to soil fertility (N, P and organic carbon) was improved significantly with Vermi Compost used either alone or in combination with fertilizer over that of initial soil status. Rashid Saleem (2017) also reported that wheat yield increased by $20 \%$ with the application of sole poultry manure @ $15 \mathrm{t} \mathrm{ha}^{-1}$ and $15 \%$ increase in response to complementary application of fertilizers in preceding seasons (Table 1). 
Table.1

\begin{tabular}{|c|c|c|c|c|c|c|c|c|}
\hline \multirow[t]{2}{*}{ Treatments } & \multicolumn{2}{|c|}{ Number of plant $/ \mathrm{m}^{2}$} & \multicolumn{2}{|c|}{ Plant Height (cm) } & \multicolumn{2}{|c|}{$\begin{array}{l}\text { 1000-grain weight } \\
\text { (g) }\end{array}$} & \multicolumn{2}{|c|}{ Grain yield $\left(\mathrm{kgha}^{-1}\right)$} \\
\hline & 2009-10 & 2009-10 & 2009-10 & 2009-10 & 2010-11 & 2010-11 & 2010-11 & 2010-11 \\
\hline \multicolumn{9}{|l|}{ Varieties } \\
\hline $\operatorname{Kent}\left(\mathbf{V}_{1}\right)$ & 9.46 & 165.25 & 236.78 & 2956.85 & 3316.45 & 238.12 & 163.95 & 9.32 \\
\hline JHO $822\left(V_{2}\right)$ & 9.33 & 156.96 & 239.64 & 3259.59 & 3564.14 & 241.45 & 158.56 & 9.05 \\
\hline JHO $851\left(V_{3}\right)$ & 9.41 & 162.25 & 234.12 & 3284.98 & 3373.98 & 236.22 & 161.23 & 9.13 \\
\hline SEm \pm & 0.17 & 3.75 & 3.68 & 125.69 & 113.56 & 4.25 & 3.45 & 0.17 \\
\hline CD $(5 \%)$ & NS & 9.56 & NS & NS & NS & NS & 8.78 & NS \\
\hline \multicolumn{9}{|l|}{$\begin{array}{l}\text { Fertilizer } \\
\text { Management }\end{array}$} \\
\hline $50 \%$ of RDF $\left(F_{1}\right)$ & 9.31 & 139.71 & 232.67 & 2983.59 & 3376.85 & 234.32 & 142.25 & 9.11 \\
\hline $75 \%$ of RDF $\left(F_{2}\right)$ & 9.32 & 152.56 & 240.87 & 3284.75 & 3420.35 & 242.54 & 147.99 & 9.05 \\
\hline $100 \%$ of $\mathrm{RDF}\left(\mathrm{F}_{3}\right)$ & 9.41 & 159.85 & 245.56 & 3476.85 & 3459.85 & 246.78 & 145.26 & 9.23 \\
\hline $\begin{array}{l}50 \% \text { of RDF + } \\
\text { Vermi Compost }\left(F_{4}\right)\end{array}$ & 9.46 & 154.89 & 249.48 & 4167.75 & 4578.23 & 251.46 & 158.89 & 9.31 \\
\hline $\begin{array}{l}50 \% \text { of RDF }+ \\
\text { Azotobactor }\left(F_{5}\right)\end{array}$ & 9.44 & 148.89 & 243.12 & 4058.46 & 4167.85 & 243.89 & 149.58 & 9.38 \\
\hline $\begin{array}{l}50 \% \text { of RDF + } \\
\text { Vermi Compost + } \\
\text { Azotobactor }\left(\mathrm{F}_{6}\right)\end{array}$ & 9.62 & 167.25 & 249.89 & 4589.56 & 4798.56 & 253.45 & 163.59 & 9.52 \\
\hline $\begin{array}{l}75 \% \text { of RDF + } \\
\text { Vermi Compost }\left(\mathrm{F}_{7}\right)\end{array}$ & 9.56 & 171.25 & 247.48 & 4570.24 & 4695.85 & 249.25 & 173.56 & 9.61 \\
\hline $\begin{array}{l}75 \% \text { of RDF + } \\
\text { Azotobactor }\left(\mathbf{F}_{8}\right)\end{array}$ & 9.51 & 165.89 & 246.89 & 4552.59 & 4896.36 & 248.46 & 169.56 & 9.48 \\
\hline $\begin{array}{l}75 \% \text { of RDF }+ \\
\text { Vermi Compost + } \\
\text { Azotobactor }\left(\mathbf{F}_{9}\right)\end{array}$ & 9.67 & 179.25 & 253.15 & 4732.56 & 5412.56 & 255.22 & 183.59 & 9.61 \\
\hline SEm \pm & 0.08 & 3.93 & 2.85 & 112.58 & 109.85 & 3.54 & 3.59 & 0.09 \\
\hline CD $(5 \%)$ & 0.25 & 9.74 & 6.11 & 325.25 & 296.89 & 8.97 & 9.12 & 0.26 \\
\hline
\end{tabular}


Better yield was achieved due to increased fertility because leguminous crops enriched soil through fixation of atmospheric nitrogen in their root nodules, which in turn supply residual food nutrients to the succeeding crop. Secondly, poultry manure application not only supplied residual nutrients for the following crop but also reduced the bulk density of soil.

\section{References}

Eghball B, Ginting D, Gilley JE (2014). Residual effects of manure and compost applications on corn production and soil properties. Agron. J. 96:442-447.

Hirzel, J., I. Walter, P. Undurraga, and M. Cartagena. (2007). Residual effects of poultry litter on silage maize (Zea mays L.) growth and soil properties derived from volcanic ash. Soil Sci. Plant Nutr. 53:480-488.

Jensen, L.S., I.S. Pedersen, T.B. Hansen, and N.E. Nielsen. (2015). Turnover and fate of $15 \mathrm{~N}$-labelled cattle slurry ammonium-N applied in the autumn to winter wheat. Eur. J. Agron. 12:23-35.
Rashid Saleem (2017). Economic feasibility of integrated nutrient management for sustainable rainfed maize-legume based intercropping systems. $\mathrm{PhD}$ thesis. Department of Agronomy, Faculty of Crop and Food Sciences, Pir Mehr Ali Shah Arid Agriculture University Rawalpindi, Pakistan.

Rowell, D. L. (1994). Soil science: Methods and applications. 350pp: John Willey \& Sons, Ins 605 Third Avenue, New York, USA.

Sainz, H.R., H.E. Echeverría, and P.A. Barbieri. (2004). Nitrogen balance as affected by application time and nitrogen fertilizer rate in irrigated notillage maize. Agron. J. 96:1622-1631.

Sorensen, P. and Amato, M. (2002). Remineralisation and residual effects of $\mathrm{N}$ after application of pig slurry to soil. European Journal of Agronomy, 16, 81-95.

Warren, G.1 (1992): Fertilizer Phosphorus. Sorption and Residual Value in Tropical African Soils. AR! Bulletin 37, Natural Resources Institute, Catham, UK.

\section{How to cite this article:}

Alankar Singh, Pallavi and Dubey, S.N. 2019. Effect of Integrated Nutrient Management of Oat on Succeeding Maize Crop. Int.J.Curr.Microbiol.App.Sci. 8(02): 1011-1014.

doi: https://doi.org/10.20546/ijcmas.2019.802.117 